\title{
Idea compassio fraterna w parenetycznej instrukcji Dhuody z Septymanii († ok. 843)
}

Enchiridion Dhuody, jak słusznie zauważyła Ursula VonesLiebenstein, zaczął cieszyć się szczególnym zainteresowaniem uczonych wraz z końcem lat 70-tych dwudziestego stulecia, które oznaczały pojawienie się i stopniowe popularyzowanie badań nad szeroko rozumianą historią społeczną kobiet ${ }^{2}$. Do dnia dzisiejszego Liber manualis został przetłumaczony na język niemiecki, francuski, angielski, włoski, kataloński i hiszpański ${ }^{3}$. Prywatne w swym wydźwięku dzieło karolińskiej arystokratki stało się przedmiotem dogłębnych badań historycznych ${ }^{4}$, li-

1 Dr Małgorzata Chudzikowska-Wołoszyn, adiunkt w Pracowni Historii Starożytnej i Kultury Antycznej, w Zakładzie Historii Starożytnej i Średniowiecznej, w Instytucie Historii i Stosunków Międzynarodowych Uniwersytetu Warmińsko-Mazurskiego w Olsztynie, e-mail: m.chudzikowska@uwm.edu.pl, ORCID: 0000-0001-5631-7259.

2 U. Vones-Liebenstein, Das Manuale der Dhuoda. Ein fürstenspiegel in form des briefes einer mutter an ihren sohn, w: Epistola 1. Écriture et genre épistolaires IV-XI siècle, red. T. Deswarte - K. Herbers - H. Sirantoine, Madrid 2018, 273-274.

3 Na temat wydań patrz: F. Sedlmeier, Laienparänetischen Schriften der Karolinge rzeit: Untersuchungen zu ausgewählten Texten des Paulinus von Aquileia, Alkuins, Jonas von Orleans, Dhuodas und Hinkmars von Reims, Neuried 2000, 373-376.

4 Spośród bogatej europejskiej literatury poświęconej Dhuodzie, bądź też arystokratkom w dobie karolińskiej, wymienić należy m.in.: J. Wollasch, Eine adlige Familie des früher Mittelalters. Ihr Selbstverständnis und ihre Wirklichkeit, „Archiv für Kulturgeschichte" 39 (1957) 150-188; G. Misch, Geschichte der Autobiographie, t. II/ 1-2, Frankfurt 1955, 471-474; S. Wemple, Women in Frankish Society, Philadelphia 1984; Y. Bessmertny, Le monde vu par une femme noble au IXe siècle. La perception du monde dans l'aristocratie carolingienne, „Le Moyen Âge, Revue d'histoire et de philologie” 93 (1987) 161-184; J.L. Nelson, Women and the world in the earlier middle ages, w: Women in the Church, red. W.J. Sheils - D. Wood, Studies in Church History 27, Oxford 1990, 53-78; M.A. Claussen, Fathers of Power and Mothers of Authority: Dhuoda and the Liber manualis, „French Historical Studies” 19 (1996) nr 3, 785-809; R. Malan, The 
terackich ${ }^{5}$, a także teologicznych ${ }^{6}$. Pismo Dhuody reprezentuje popularny od schyłku VIII wieku i utrzymujący się do końca IX wieku typ utworów dydaktycznych i wzorcotwórczych, które późniejsza literatura określiła mianem speculum.

Liber manualis zaliczany jest ściśle do grupy specula laicalium, czyli zwierciadeł pisanych z myślą o etycznej formacji świeckich arystokratów ${ }^{7}$.

Ancestry of Dhuoda, Duchess of Septimania, „The Genealogist” 11 (1997) nr 1, 116-126; J.L. Nelson, Dhuoda, w: Lay intellectuals in the Carolingian world, red. P. Wormald - J.L. Nelson, Cambridge 2007, 106-120; V.L. Garver, Women and Aristocratic Culture in the Carolingian World, London 2009.

5 Zob. np. M. Manitius, Geschichte der Lateinischen Literatur des Mittelalters, t. 1, München 1959, 442-444; F.J.E. Raby, A History of Secular Latin Poetry in the Middle Ages, t. 1-2, Oxford 1957, 218-219; F. Brunhölzl, Geschichte der lateinischen Literatur des Mittelalters, t. 1, Munich 1975, 407-409; B. Löfstedt, Zu Dhuodas Liber Manualis, „Arctos” 15 (1981) 67-83; P. Dronke, Women writers of the middle ages. A Critical Study of Text from Perpetua to Marguerite Porete, Cambridge 1984, 36-54; J. Marchand, The Frankish Mother. Dhuoda, w: Medieval Women Writers, red. K.M. Wilson, Manchester 1984, 12-28; K. Cherewatuk, Speculum Matris: Dhuoda's Manual, „Florilegium” 10 (1988-1991) 49-64; M.G. Bianco, Aspetti di quotidianità culturale nel Liber Manualis di Dhuoda: Il libro, l'autrice, il destinatorio, w: Percepta rependere dona. Studi di filologia per Anna Maria Luiselli Fadda, red. C. Bologna - M. Mocan - P. Vaciago, Firenze 2010, $1-20$.

6 M.A. Claussen, God and Man in Dhuoda's Liber Manualis, w: Women in the Church, red. W.J. Sheils - D. Wood, Studies in Church History 27, Oxford 1990, 43-52; G.W. Olsen, One Heart and One Soul (Acts 4:32 and 34) in Dhuoda's Manual, „Church History" 61 (1992) nr 1, 23-33; M.A. Mayeski, Dhuoda. Ninth Century Mother and Theologian, Scranton 1995; M. Rodriguez, Los Salmos bíblicos como enseñanza en el Manual de Dhuoda, w: Actas III Congreso Hispánico de Latín Medieval, t. 2, León 2002, 447-456; J. Meyers, Dhuoda et la Justice d'après son Liber Manualis (IX siècle), „Cahiers de Recherches Médiévales et Humanistes. Journal of Medieval and Humanistic Studies" 25 (2013) 451-462.

7 Należy dodać, że teksty wpisujące się w nurt tzw. świeckich luster przez długi okres czasu uznawane były przez historyków za niewiele wnoszące czy też wręcz bezużyteczne w badaniu dziejów wczesnego średniowiecza. Wniosek ten uzasadniano tzw. odtwórczą formułą zwierciadeł. Przypominały one bowiem rozbudowane florilegia, które obficie czerpały z ksiąg biblijnych oraz, w drugiej kolejności, z pism patrystycznych. Autorzy wkomponowywali je w mniej lub bardziej rozwiniętą autorską strukturę. Naukowe zainteresowanie gatunkiem speculum laicalis pojawiło się więc stosunkowo niedawno, podobnie zresztą do ożywionej badawczej atencji względem sylwetki i dzieła samej Dhuody. Pomimo, że zwierciadła świeckie przypominają dzieła wpisujące się w jeden utarty kanon i schemat, to - jak zauważył Pierre Tourbert - ich szczegółowa analiza pozwala dostrzec w pełni zindywidualizowaną zawartość. Były pisane i subtelnie dostosowywane do swoich odbiorców. To stanowić może o ich sile i oryginalności. Por. P. 
Epoka karolińska przyniosła nam cztery znane zwierciadła, których odbiorcami byli świeccy możni ${ }^{8}$. Były to w kolejności Liber exhortationis Paulina z Akwilei (ur. ok. 750), które napisane zostało tuż przed 795 rokiem dla Eryka diuka Friuli († 799), następnie pismo De virtutibus et vitiis Alkuina z Yorku (ok.737-804), zadedykowane tuż po 800 roku hrabiemu marchii bretońskiej Widonowi († ok. 819). Kolejne speculum świeckie De institutione laicali skomponował biskup Jonasz z Orleanu (ur. ok. 780) w 829 roku dla hrabiego Matfryda († 836). Podręcznik Dhuody Liber manualis był najprawdopodobniej ostatnim z napisanych w IX wieku luster dla laików ${ }^{9}$. Markiza przystąpiła do pisania dzieła 30 listopada 841 roku, a skończyła 2 lutego 843 roku $^{10}$. Zaadresowała je do swojego pierworod-

Toubert, La théorie du mariage chez les moralistes carolingiens, w: Il matrimonio nella società altomedievale, 22-28 aprile 1976, t. 2, Spoleto 1977, 244. Zob. także wnioski w: Sedlmeier, Laienparänetischen Schriften der Karolingerzeit, s. 520-539.

8 Na temat zwierciadeł świeckich prócz wspomnianej pracy F. Sedlemeiera zob. także: R. Stone, Morality and Masculanity in the Carolingian Empire, Cambridge 2012, $36-42$.

9 Po Dhuodzie zwierciadła pisał także biskup Hinkmar z Reims († 882). Około 869 roku skomponował rozprawę De cavendis vitiis et virtutibus exercendis, którą zadedykował królowi Karolowi Łysemu (823-877). Biorąc pod uwagę adresata, dzieło powinno znaleźć się w grupie speculum regis, czyli zwierciadeł pisanych dla władców. Jednak prywatny charakter pisma może skłaniać do zaliczenia je w poczet zwierciadeł dla świeckich. (Za taką klasyfikacją opowiadała się Doris Nachtmann. Por. D. Nachtmann, Einleitung, w: Hinkmar von Reims, De cavendis vitiis et virtutibus exercendis, red. D. Nachtmann, MGH, QQ zur Geistesgesch 16, München 1998, 13. Również Franz Sedlemeier umieścił De cavendis vitiis et virtutibus exercendis na liście omawianych w swej monografii świeckich luster. Por. Sedlmeier, Laienparänetischen Schriften der Karolingerzeit, s. 451-518). Hinkmar nie definiował zadań monarchy na płaszczyźnie państwowej i politycznej, ta tematyka była z kolei typowa dla parenezy królewskiej. Odniósł się jedynie do religijnych i duchowych aspektów życia władcy. Podjął, zgodną z tematem, rozbudowaną wykładnię cnót i wad, co także zbliża utwór do gałęzi speculum laicalis.

10 Informację tę podała w Liber manualis. Por. Dhuoda, Liber manualis Dhuodane quem ad filium suum transmisit Wilhelmum XI 2, w: Manuel pour mon fils, red. P. Riché, SCh 225, Paris 1997, 368-370: „Incoatio huius libelli II $^{\circ}$ anno obitus Ludouci condam imperatori, $\mathrm{II}^{\circ}$ kalendas decembri, sancti Andreae missa, incoante sanctum Domini Aduentum. Finitus est autem, auxiliante Deo, IIII $^{\circ}$ nonas februarii, Purificationis sanctae et gloriosae semperque uirginis Mariae, Christo propitio regnante, et regem quem Deus dederit sperantem" - 'Początek tej książeczki sporządziłam w drugim roku po śmierci cesarza Ludwika (Pobożnego), dwa dni przed kalendami grudnia (30 listopada) w dniu wspomnienia świętego Andrzeja, wraz z początkiem adwentu Pana. Została zaś ona z Bożą pomocą ukończona cztery dni przed nonami lutego (2 lutego), w święto Oczyszczenia Najświętszej Marii Panny'. Święto Oczyszczenia NMP nazywane jest także 
nego szesnastoletniego syna Wilhelma (826-850), który w tym czasie ze względu na trwającą $\mathrm{w}$ imperium karolińskim wojnę domową przebywał $\mathrm{z}$ dala od niej ${ }^{11}$.

W prologu do swojej wzorcotwórczej instrukcji autorka podkreśliła, że jej intencją było napisanie ,dziełka” (opusculum) pełniącego rolę podręcznika (manualis) i zwierciadła (speculum). W nim Wilhelm, niczym w lustrze, miał dostrzec zbawienie swojej duszy (salutem animae tuae) oraz odpowiednie upodobanie w realizacji doczesnych zadań. Zobowiązywała się do pokazania synowi, jak podobając się Bogu, być użytecznym dla świata (qualiter possis utilis esse saeculo) ${ }^{12}$. Świata intensywnych przemian społecznych, politycznych i religijnych. Najbardziej zależało jej jednak na przedstawieniu Wilhelmowi swojej osobistej, opartej na Bogu przestrzeni, w której dostrzec można było oczywiście różnorodność zewnętrznych obrazów. Liber manualis pełnił zatem, co należy podkreślić, rolę zwierciadła jej własnej duszy ${ }^{13}$. Dhuoda chciała, aby Wilhelm zobaczył w podręczniku nią samą. Usłyszał słowa, których nie mogła wypowiedzieć in persona. Jej świadomym celem było zaznaczenie swojej trwałej obecności w życiu syna. Wiedziała, że jedyną możliwością kontaktu z pierworodnym będzie skomponowanie dla niego umiejętnie zredagowanego słowa. Warto zwrócić uwagę, że pozostawiona przez arystokratkę książka, którą można rozpatrywać zarówno jako duchowy testament, pamiętnik, a nawet list wyróżnia się charakterystycznym głębokim autobiografizmem i macierzyńską emocjonalnością. Pismo miało przede wszystkim sprawić, aby syn poznał matkę, następnie zaś - czytając jej liczne rady - uzyskał niezbędną formację duchową, moralną oraz intelektualną.

Dhuoda dołożyła wszelkich starań, aby za pośrednictwem Liber manualis móc dopełnić i zrealizować przypisaną jej społeczną rolę, a także ministerium. Wierzyła, że będąc matką szlachetnie urodzonego męskiego potomka, predestynowanego do pełnienia ważnych społecznych ról i funkcji, winna była zrealizować się jako jego wychowawczyni, nauczycielka oraz moralna przewodniczka ${ }^{14}$. Współodpowiedzialność za edukację religijną

świętem Matki Bożej Gromnicznej. Wszystkie tłumaczenia Liber manualis pochodzą od autorki.

11 Wilhelm wyjechał z rodzinnej Septymanii i majątku w Uzès wraz z ojcem Bernardem z Septymanii († 844). Po przegranej dla nich walce pod Fontenay-en-Puisaye (25 VI 841) trafił jako zakładnik w ręce zwycięskiego Karola Łysego.

12 Por. Liber manualis, Prologus, SCh 225, 80-81.

13 Por. Mayesky, Dhuoda. Ninth Century Mother and Theologian, s. 28.

14 Por. Liber manualis I 7, SCh 225, 114-115: „Ortatrix tua Dhuoda semper adest, fili, et si defuerim deficiens, quod futurum est, habes hic memoriale libellum moralis, et quasi in picturam speculi, me mente et corpore legendo et Deum deprecando, intueri 
i społeczną dzieci była jedną z podstawowych wartości i cnót, którymi wyróżniać się powinna karolińska arystokratka. Taki przekaz dają nam źródła powstałe już w dobie merowińskiej ${ }^{15}$. Później przez cały ósmy i dziewiąty wiek $\mathrm{w}$ piśmiennictwie utrwalany będzie ideał roztropności, dzięki któremu kobiety mogły zapewnić swojemu potomstwu odpowiednią edukację moralną ${ }^{16}$.

Liber manualis pokazuje nam, że pod względem podejmowanych wątków w znacznym stopniu zachowuje utrwaloną w tym typie dzieł stałą koncepcję tematyczną. W przekazywanych przez markizę normach moralnych pojawia się znana i realizowana zarówno w zwierciadłach świeckich, jak i królewskich nauka o cnotach, a także popularna idea walki z grzechami i pokusami. Dzieło Dhuody jednak znacznie rozbudowuje sam wątek aretologiczny. W licznych i drobiazgowych wykładach autorka namawiała syna do praktykowania całego szeregu cnót. Obok cnót teologalnych i kardynalnych pojawia się również nacisk na dary płynące na drodze otwarcia na działanie Ducha Świętego czy wreszcie postawy, które można było uzyskać, skwapliwie realizując w swym życiu osiem Chrystusowych błogosławieństw. Wszystkie wymienione przez arystokratkę sprawności, cnoty i postawy stanowiły przemyślaną metaforyczną drabinę do nieba, a także jej kolejne stopnie prowadzące do osiągnięcia chrześcijańskiej doskonałości.

possis, et quid erga me obsequi debeas pleniter inueniri potes. Fili, habebis doctores qui te plura et ampliora utilitatis doceant documenta, sed non aequali conditione, animo ardentis in pectore, sicut ego genitrix tua, fili primogenite" - 'Ja, Dhuoda, jestem zawsze obecna, jestem twoim pokrzepieniem i gdyby mnie zabrakło, co zaiste nastąpi, masz tę moralną książeczkę jako wspomnienie o mnie i tak jak w zwierciadle będziesz mógł mnie zobaczyć, czytając razem z moim umyłem i ciałem, modląc się do Boga, a to, co mógłbyś usłyszeć ode mnie, znajdziesz w pełni tutaj. Synu, będziesz miał nauczycieli, którzy będą mogli udzielić ci lepszych i bardziej pożytecznych wskazówek, lecz oni nie mają takiego statusu jak ja, nie mają serca bardziej płonącego w piersi niż ja, twoja matka, mój synu pierworodny!'.

15 Znaczącą dla omawianej wychowawczej roli matek jest zachowana korespondencja merowińskiej możnej Herchenefredy, żony Salwiusza reprezentującego znany galorzymski ród Syagriuszy. Herchenefreda ok. 630 roku napisała trzy listy do ukochanego syna Dezyderiusza (ok. 590-655), który rozpoczynał karierę urzędniczą. Arystokratka w listach podkreśliła, że poprzez nieustanną troskę o zbawienie syna wypełnia, dane Bogu, przyrzeczenie. Por. Epistolae Herchenefredae, w: Vita Desiderii Cadurcae urbis episcopi, red. B. Krusch, MGH, SS rer. Merov. 4, Hannover 1902, 569-570.

16 Por. Garver, Women and Aristocratic Culture in the Carolingian World, s. 123. Na temat tradycji wychowawczej matek w społeczeństwie merowińskim i karolińskim, zob. także: Olsen, One Heart and One Soul, s. 27; S.F. Wemple, Women in Frankish Society: Marriage and the Cloister 500 to 900, Philadelphia 1981, 103 i 125. 
Szczególne interesujące w Liber manualis są wzmiankowane przez autorkę kwestie społeczne, rodzinne, a także polityczne. Pod tym względem pismo to znacznie wyróżnia się na tle pozostałych zwierciadeł dla świeckich. Dostarcza nam wielu cennych refleksji na temat relacji, stosunków oraz ról społecznych. Odnajdujemy w nim echo utrwalonych klasowych zależności, a także obowiązujących reguł i wartości. Dhuoda w dużej mierze jednak, co należy podkreślić, odwoływała się do całego szeregu wyobrażeń dotyczących idealnego porządku społecznego oraz funkcjonowania chrześcijańskiej wspólnoty. Taka sytuacja jest zrozumiała w kontekście współczesnych autorce wielu społecznych napięć i konfliktów, których źródłem była niewątpliwie zaogniona walka o władzę pomiędzy synami Ludwika Pobożnego (778-840) oraz nieodwracalny podział karolińskiego imperium. Na tym tle w ustawodawstwie, moralistyce oraz homiletyce karolińskiej pojawiły się liczne treści poświęcone właściwemu rozumieniu miłości braterskiej, a także pojęciu idealnego braterstwa ${ }^{17}$. Proklamowana w nich idea caritas fraterna i dilectio fraterna ${ }^{18}$ łączyła w sobie świeckie

17 Na temat więzi braterskich we wczesnym średniowieczu i ich wielorakich interpretacji szczegółowo w pracy: A. Pieniądz, Więzi braterskie we wczesnym średniowieczu. Wyobrażenia i praktyka społeczna, Tyniec 2014.

18 O znaczeniu, konsekwencjach naruszenia, a także łasce płynącej z budowania miłości braterskiej, której ideałem była doskonała relacja pierwszych Apostołów, wypowiadały się liczne synody karolińskie IX wieku, m.in. synod paryski z 825 roku (zob. Concilium Parisiense, a. 825, 44, cap. 76, red. A. Werminghoff, MGH, Conc. 2, 2, Hannover 1908, 521: „Certum est enim, quia, sicut quisquam, si eandem caritatem, illam Deo placitae fraternitatis caritatem, servare poterit et noluerit, ad palatium caritatis pervenire non poterit, ita, si illos, quos contra eandem dilectionis unitatem dissidentes cognoverit et illos ad tantae beatitudinis viam revocare poterit et virtute, qua valet, non certaverit, ipse sibi eiusdem beatitudinis ianuam seris valdissimis claudit".), następnie synod zwołany także w Paryżu w 829 roku (zob. Concilium Parisiense, a. 829, 50, cap. 61, MGH, Conc. 2, 2, 657: „[...] Christus in nobis idem est, qui et in illis; sed non idem animus in nobis, qui fuit in illis; eadem fides in nobis, sed non eadem devotio. In illis (apostolis) enim maior erat fraternitas Christi quam sanguinis; in illis sicut una fides, ita erat et una substantia, ut, quibus erat communis Christus, communis esset et sumptus. [...] Tunc enim sub apostolis tanta fraternitatis dilectio fuit, ut in conventu suo nulla inveniretur indigentia; tanta autem modo christianitatis dissimulatio est, ut in coetu nostro vix invenias locupletem” oraz cap. 92, 678: „Nam et hoc humiliter obsecrando admonemus, ut liberos vestros, quos vobis divina pietas largiri voluit, in timore Dei iugiter diligenterque erudiatis, sicuti et facitis, et, ut in mutuae dilectionis caritate et fraternitatis amore atque unanimitatis concordia vicissim consistant". To samo zalecenie znalazło się w aktach późniejszego synodu akwizgrańskiego z 836 roku. Zob. Concilium Aquisgranense, a. 836, 56, cap. 53, MGH, Conc. 2, 2, 720). Duchowe braterstwo pojawia się także w zwierciadle Jonasza z Orleanu (zob. Jonas Aurelianensis episcopus, De institutione laicali 1, 20, PL 
rozumienie braterstwa biologicznego, które oparte było na altruistycznym współdzieleniu dziedzictwa ${ }^{19}$ i rodzinnym współdziałaniu oraz chrześcijański wzorzec braterstwa duchowego łączącego wszystkich ochrzczonych na drodze pełnego zaufania i wierności ${ }^{20}$. Koncepcja tak rozumianej wspólnoty pojawiła również w Podręczniku Dhuody. Karolińska autorka w swoich rozważaniach skoncentrowała się przede wszystkim na pojęciu chrześcijańskiej wspólnoty braterskiej, której podstawowym spoiwem była głoszona przez nią compassio fraterna. Równolegle z braterstwem mistycznym w Liber manualis pojawiła się także definicja braterstwa biologicznego, małej wspólnoty rodzinnej połączonej w wyobrażeniu Dhuody prócz miłości i oddania również szczegółowymi obowiązkami wychowawczymi i edukacyjnymi.

Należy zwrócić uwagę, że dla Dhuody, tak samo jak dla innych wczesnośredniowiecznych autorów, miłość braterska w rozumieniu miłości biologicznej była tożsama z miłością duchową łączącą wszystkich wiernych w Chrystusie ${ }^{21}$. Jej podstawę stanowiła koncepcja braterstwa, którą głosił w swoim nauczaniu św. Paweł. Karolińska autorka zwróciła Wilhelmowi

106, 161-165). Użyte zostaje ono w kontekście wykładu na temat apostolskiej miłości, która obecna była w pierwotnych wspólnotach kościelnych, jednak zabrakło jej, nad czym ubolewał biskup Orleanu, we współczesnym mu społeczeństwie karolińskim. Okazuje się, że zdecydowana większość zamkniętych w rozdziale dwudziestym De institutione laicali rozważań jest tożsama ze wspomnianym sześćdziesiątym pierwszym ustępem paryskich akt z 829 roku, których redaktorem był zresztą sam Jonasz. Duchowny, komponując swój moralny podręcznik, włączył do niego dość sporo odpowiadającego mu pod względem treściowym materiału synodalnego. Pośród późniejszych moralistów karolińskich, którzy opiewali sakralny wymiar miłości braterskiej, był m.in. Raban Maur (ok. 780). Zob. De charitate, w: Rabanus Maurus, Homiliae de festis praecipuis, PL 110, 86: „Quapropter, fratres charissimi, sectemini charitatem: ipsa videlicet est dulce ac salubre vinculum mentium, sine qua dives pauper est, et cum qua pauper dives est. Haec in adversitatibus tolerat, in prosperitatibus temperat, in duris passionibus fortis, in bonis operibus hilaris, in tentationibus tutissima, in hospitalitate latissima, inter vos fratres jucundissima, intra falsos etiam patientissima: [...]". Należał do nich także Paschazjusz Radbert (ok. 790-865). Zob. Paschasius Radbertus, De fide, spe et charitate 3, 9, PL 120, 1475: „Nam dilectio proximi germanitatem servat, germanitas autem in adoptionem transit, adoptio vero per gratiam filios Dei nos efficit. Hinc quoque quia fratres et filii uni Patrifamilias sumus, haereditas coelestis fide et substantia hujus mundi communis nobis est. Sic ergo largire debemus proximis, quasi cohaeredibus, et quod eorum est singulis non negare: quia secundum Apostolum, nihil aliud debere debemus, nisi ut invicem diligamus".

19 W dziedzictwie tym w sposób szczególny wskazywano na wspólne władztwo wszystkich królewskich synów, które mogłoby zapobiec podziałowi imperium.

20 Por. Pieniądz, Więzi braterskie we wczesnym średniowieczu, s. 136.

21 Por. Pieniądz, Więzi braterskie we wczesnym średniowieczu, s. 141. 
uwagę, że ,zgodnie ze słowami i zachętami Apostołów, jeden powinien nosić brzemiona drugiego" 22 . Odnajdujemy w tym miejscu echo listu do Galatów, w którym św. Paweł, wzywając członków pierwotnej wspólnoty chrześcijańskiej do braterskiej solidarności i oddania, powiedział: ,Jeden drugiego brzemiona noście i tak wypełniajcie prawo Chrystusowe"23. Idea pozytywnej więzi emocjonalnej, która w sposób naturalny ze względu na związek krwi towarzyszyć powinna rodzeństwu, przeniesiona została na wspólnotę wiernych i stała się elementem opisu jej porządku ${ }^{24}$. Braterstwo duchowe i powiązaną z nim mistyczną współzależność traktowano jednak ponad braterstwem, które odnosiło się do więzów krwi, czyli braterstwa biologicznego. W podręczniku Dhuody oba pojęcia fraternitas pojawiają się we wspólnym kontekście wiążącym się z głęboką chrześcijańską miłością. Autorka nie tylko starała się przybliżyć pierworodnemu synowi prawdziwe znaczenie duchowej więzi międzyludzkiej i niezbędne do jej realizacji cnoty. Jako kochająca matka przypominała mu także o zobowiązaniach, które ciążyły na nim z uwagi na więź krwi, a także starszeństwo nad małoletnim bratem ${ }^{25}$. Piętnastoletni Wilhelm powinien, jak pisała autorka, zrealizować się w roli przewodnika i opiekuna młodszego brata.

22 Liber manualis III 10, SCh 225, 174: ,[...] secundum dicta uel ortamenta Apostoli, onera sua alterutrum portare".

$23 \mathrm{Ga} 6,2$.

24 Por. Pieniądz, Więzi braterskie we wczesnym średniowieczu, s. 63.

2522 marca 841 roku urodził się drugi syn Dhuody Bernard. Kilka dni po porodzie ojciec zabrał go z rodzinnej posiadłości w Uzès. Dhuoda niestety nie poznała imienia maleńkiego Bernarda aż do dnia swojej śmierci. Zmarła tuż po skończeniu dzieła w 843 roku. Synowie markizy w 841 roku podążyli wraz z ojcem w głąb Akwitanii. W sporach sukcesyjnych, które toczyli między sobą czterej spadkobiercy Ludwika Pobożnego, Bernard zdecydował się wystąpić przeciwko swojemu dotychczasowemu suwerenowi Karolowi Łysemu. Jednak to właśnie Karol pojednany z Ludwikiem Niemieckim (806876) odniósł zwycięstwo nad pozostałymi braćmi - Pepinem II z Akwitanii (bratanek królewskich synów - 823-864) i Lotarem I (795-855), a także ze sprzymierzonymi z nimi możnymi. W tak przegranych okolicznościach mąż Dhuody zmuszony był chronić swoich synów i szukać dla siebie nowych opiekunów. Por. Liber manualis, Praefatio, SCh 225, 84: „Voluente et crescente calamitate huius saeculi miseria, inter multas fluctuationes et discordias regni, imperator praedictus uiam omnium isse non dubium est. Nam infra XXVIII anno regni eius, non perueniens ad summum, vitam saeculi debitam finiuit. Post mortem quoque eius, in anno sequente, natiuitas fratris tui XI Kalendas aprilis: ex meo secundus post te, in Vzecia urbe, Deo miserante, egressus est utero. Etenim paruulum illum, antequam baptismatis accepisset gratiam, dominus et genitor Brnardus utrique uestrum, una cum Elefanto, praedictae ciuitatis episcopo, et cum ceteris fidelibus suis, in Aquitaniae partibus ad suam fecit adduci praesentiam" - "Wtedy gdy wciąż trwały i nasilały się niepowodzenia tego świata, wśród tak licznych niestałości i niezgody w królestwie, wspo- 
Przedstawione w Liber manualis wyobrażenie braterstwa duchowego oraz braterstwa biologicznego połączone było trwałym darem, który Dhuoda określała jako compassio fraterna, czyli braterskie miłosierdzie i współczucie. Tożsame pojęcie odnajdziemy choćby w nauczaniu św. Augustyna ${ }^{26}$ i Izydora z Sewillii ${ }^{27}$. Ten rodzaj współczucia według karolińskiej uczonej wypływał z bezwarunkowej i wzajemnej miłości braterskiej i trwale związywał ze sobą wszystkich współodczuwających. Pragnęła ona, aby dokładnie taki model braterstwa poruszył Wilhelma i zapisał się trwale w jego światopoglądzie oraz czynach. W trzeciej księdze podręcznika autorka żarliwie przekonywała pierworodnego syna, że cała ludzkość doczesnego świata pod każdym względem powinna zwrócić się ku braterskiej wspólnocie uczuć (compassio fraterna). Potrzeba, aby zarówno ci silniejsi, jak i ci słabsi, co dyktowała dalej, oddawali się jej wzajemnie ${ }^{28}$. Wzór relacji, który pozostawili apostołowie, a także inni żyjący po nich ludzie był zdaniem uczonej wystarczającym świadectwem zgody i miłości braterskiej ${ }^{29}$. Namawiała

mniany cesarz (Ludwik Pobożny), nie wahając się, odszedł drogą wspólną dla wszystkich. Dokonał swego żywota zanim jeszcze dopełniło się 28 lat jego panowania. Po śmierci cesarza, w następnym roku, 11 dni przed kalendami kwietnia (22 marca 841$)$ narodził się z mojego łona, dzięki litościwemu Bogu, twój brat, w mieście Uzès. Wtedy gdy był on jeszcze bardzo mały i zanim przyjął on łaskę chrztu, pan i ojciec was obu - Bernard polecił, żeby przywieźć go do siebie w rejon Akwitanii razem z biskupem miasta Uzès Elefantusem i z pozostałymi wiernymi sobie zwolennikami'.

26 Siła compassio fraterna została przez niego podkreślona w polemice z manichejczykami. Por. Augustinus, Contra Faustum Manicheum 21, 16, PL 42, 399: „An ibi charitas non errat, ut nulla esset fraterna compassio, pro his utique quorum peccato nullo praecedente impendebant aeterna suplicia?” - „Czy może nie było miłości do tego stopnia, że nie było śladu współczucia braterskiego, że bóg skazywał na wieczne męki bez zaistnienia uprzednio żadnego grzechu?”. Tł. J. Sulowski, Św. Augustyn, Przeciw Faustusowi 21, 16, PSP 55, Warszawa 1991, 254.

27 Izydor uważał, że compassio fraterna powinna być stałym elementem i wyróżnikiem aktywnego życia chrześcijan. Doskonały chrześcijanin powinien dać się poznać jako ten, który potrafi w ciszy wznieść się i oderwać od życia aktywnego ku życiu kontemplacyjnemu, jednocześnie także wie, kiedy zejść - za sprawą cnoty współczucia braterskiego - z wyżyn kontemplacyjnych ku doczesnej aktywności. Por. Isidorus, Sententiae differentiarum de activa vita atque contemplativa, PL 83, 1243: „Illi vero perfecti esse noscuntur, qui intra Ecclesiam tempore discreto de activa vita ad contemplativam ascendere norunt, et de contemplativa ad activam descendere sciunt".

28 Por. Liber manualis III 10, SCh 225, 178: ,[...] tam in maioribus quam in minoribus per compassionis fraternitatem omnimodis per cuncta in generi humano ostendit esse tenendam".

29 Por. Liber manualis III 10, SCh 225, s. 178: „Haec enim a pluribus retro, etiam et in sanctis apostolis illorumque similibus capaces, per omnia legimus esse completum". 
Wilhelma do ciągłego podsycania i uaktywniania miłości. W Liber manualis czytamy: „Kochaj wszystkich, abyś był kochany przez wszystkich, troszcz się, aby i oni troszczyli się o ciebie. Jeśli ty (będziesz kochał) wszystkich, wszyscy - ciebie, jeśli ty (będziesz kochał) w pojedynkę, tamci w liczbie mnogiej" 30 .

W dalszej części, asymilując na potrzeby swojego wykładu gramatyczne wademekum Eliusza Donata, Dhuoda nieprzerwanie dowodziła, jak wielka i oddziałująca jest siła miłości w stosunku do bliźnich. Tymi słowami zwracała się do Wilhelma:

Napisane zostało w Sztuce poety Donata: „Kocham cię i jestem kochany przez ciebie, całuję cię i jestem przez ciebie całowany ${ }^{31}$, troszczę się o ciebie

30 Liber manualis III 10, SCh 225, s. 176: „Ama omnes ut ameris ab omnibus, dilige ut diligaris. Si tu omnes, omnes te; si tu singulariter, illi pluraliter". Dhuoda w odniesieniu do miłości używała najczęściej dwóch zamiennych określeń, było to łacińskie amor oraz dilectio, a także czasowniki amare i diligere. Rzadziej sięgała po termin caritas. Wydaje się, że nie różnicowała owych pojęć, a traktowała je zupełnie synonimicznie. Izydor z Sewilli, co istotne, uważał, że amor odnoszone jest do tych „lepszych rzeczy”, a więc bardziej wykorzystywał je w opisie miłości do Boga. Amor rozumiał jako dilectio carnalis (miłość cielesną i emocjonalną) Dilectio zaś było uczuciem, które wiązało „dwa podmioty”. Por. Isidorus, Etymologiarum libri XX 8, 2, 6-7, PL 82, 296: „ «Charitas» Graece, Latine «dilectio» interpretatur, quod duos in se «illiget». Nam dilectio a duobus incipit, quod est amor Dei at proximi, [...] Omnis autem dilectio carnalis, non dilectio, sed magis amor dici solet. Dilectionis autem nomen tantum in melioribus rebus accipi solet. Wspomnieć należy, że Dhuoda musiała w jakimś stopniu znać przedstawioną wyżej definicję i rozróżnienie etymologiczne dokonane przez Izydora. Przywoływała zresztą w nieco okrojonej wersji fragment z tego samego ustępu encyklopedii Sewilczyka, który odnosił się do pojęć wyrażających miłość. W drugiej księdze Liber manualis mówiła do Wilhelma (Liber manualis II, 3, SCh 225, 124): „Nam karitas graece, latine dicitur dilectio. Vtrumque ad summum continet pertinendum qui adoratur et colitur Deus”- „W grece bowiem karitas jest tym, czym w łacinie dilectio. A każde z tych słów obejmuje w sobie wszystko, co odnosi się do Tego, który jest adorowany i czczony jako Bóg”. Por. Isidorus, Etymologiarum libri XX 8, 2, 6, Migne PL 82, 296). Pomimo tego, że autorka przejawiała pewną zauważalną wiedzę na temat różnic interpretacyjnych pojawiających się pomiędzy łacińskimi słowami amor i dilectio, to jednak aż do końca dzieła korzystała $\mathrm{z}$ obu terminów zupełnie dowolnie i zamiennie. Na temat używanych przez Dhuodę leksykalnych symboli miłości, zob. H. Hummer, Vision of Kingship in Medieval Europe, Oxford 2018, 219-230.

31 Dhuoda dobrze znała podręcznik gramatyki autorstwa Donata. W zacytowanym przez nią fragmencie dostrzec można echo odmiany koniugacyjnej, którą rzymski gramatyk zawarł w rozdziale De verbo swojej rozprawy - Ars minor. Por. Probus Donatus Servius, Ars Minor, w: Grammatici Latini, vol. 4, red. H. Keil, Leipzig 1864, 360. 
i ty troszczysz się o mnie; uznaję cię i jestem uznawany przez ciebie”. I dalej - „Ja, mnie, dla mnie, ode mnie i - o! - Przeze mnie”. I w liczbie mnogiej: „,ich, spośród nich, im i - o! - przez nich, [...]”32.

Włączenie przez Dhuodę gramatyki Donata do teologicznych rozważań nad istotą miłości niewątpliwie było zabiegiem nowatorskim i oryginalnym. Okazuje się, że matka zaproponowała Wilhelmowi kilkupłaszczyznowy ciekawy wykład. Wychodząc od zabawy słowem, na jej kanwie zbudowała przestrzeń do dalszych moralnych i duchowych interpretacji. Elementarz Donata był lekturą znaną całej ówczesnej łacińskiej Europie, powszechnie też stosowaną w edukacji. Nie ma wątpliwości, że karolińska uczona odwołała się do tej pozycji podręcznikowej w sposób zupełnie przemyślany. Przypominając powszechnie znane i być może banalne dla szesnastoletniego Wilhelma paradygmaty gramatyczne, wzniosła się ku paradygmatom moralnym. W metodzie, którą przyjęła, po raz kolejny daje o sobie znać silna potrzeba zapewnienia potomstwu podstawowej formacji zarówno na płaszczyźnie moralnej, jak i intelektualnej.

Wzajemna altruistyczna miłość, którą proponowała Dhuoda, miała budować społeczeństwo oraz ludzkie relacje. Zawierała także ważny element szacunku, pełnej akceptacji oraz uznania drugiego człowieka. Nie był to rodzaj miłości, którą powiązać można by było ściśle z klasyczną chrześcijańską agape, lecz bardziej - jak przekonywał Glenn Olsen - z silnym partnerskim i obopólnym uczuciem mającym na celu uznawanie, dawanie i odwzajemnianie ${ }^{33}$. Taki format braterskiej miłości autorka wspominała w następującym fragmencie: „Tak więc ty, mój synu Wilhelmie, troszcz się i doceniaj każdego, przez którego sam chcesz być doceniany, kochaj, czcij, przyjmuj i szanuj wszystkich, abyś mógł także zasłużyć sobie z ich strony na wzajemną korzyść i należyty honor"34.

Najwymowniejszy przykład braterskiego oddania i zaufania można było jej zdaniem zaobserwować w zachowaniu jeleni przekraczających rzekę. Posłużyła się tutaj znaną z nauczania św. Augustyna i św. Grzegorza metaforą współodpowiedzialności, która wyrażona była w sposobie, w ja-

32 Por. Liber manualis III 10, SCh 225, 176: „Scriptum est in Arte Donati poetae: «Amo te et amor a te, osculor te et osculor a te, diligo te et diligor a te; agnosco te et agnoscor a te». Et iterum: «Ego, mei uel mis, mihi uel a me, et o, a me». Et pluraliter: «Illos, illorum et illis, o, ab illis»; et cetera his pertinentium similia". Por. Probus Donatus Servius, Ars Minor, De Pronomine II 12, 381.

33 Por. Olsen, One Heart and One Soul, s. 29.

34 Liber manualis III 10, SCh 225, 178: „Tu ergo, fili Wilhelme, dilige et agnosce a quo uel a quibus agnosci cupis; ama, uenera, collige et honora omnes, ut ab omnibus uicissitudinis retributionem cum honoris pensum merearis acipere". 
kim jelenie radziły sobie z przeciwnościami. Punktem wyjścia do rozważań autorki Liber manualis stał się biblijny motyw jelenia pragnącego źródeł wodnych (Ps 41,2) ${ }^{35}$. Był to niezwykle budujący w opinii autorki przykład, który wcześniej przedstawił już „pewien uczony”36. Trudno jednoznacznie odpowiedzieć, czy Dhuoda miała w tym miejscu na myśli Augustyna i jego komentarz do Księgi Psalmów czy też bardziej moralną interpretację Księgi Hioba napisaną przez Grzegorza Wielkiego. Okazuje się, że obaj wielcy egzegeci, komentując biblijny tekst, wykorzystali ów znany piśmiennictwu chrześcijańskiemu topos czynnego braterstwa, który sięgał do pełnego ofiarności usposobienia jeleni. Karolińska autorka wiedziona erudycją ojców Kościoła przedstawiła Wilhelmowi następujący obraz absolutnej jedności:

Jelenie mają taki zwyczaj postępowania, że gdy stadnie zaczynają przeprawiać się przez morza albo rozległe rzeki z burzliwymi wirami, wówczas jeden kładzie swoją głowę i rogi na grzbiecie drugiego tak, że łączą się ze sobą szyjami, po to aby pokrótce odpoczywając, mogły łatwo i żwawo przekroczyć strumień. Jest $\mathrm{w}$ nich taka inteligencja i tak wyważony instynkt, że gdy wyczują u tego pierwszego nadmierne obciążenie, zamieniają go na ostatniego, a następnego wybierają, aby był pierwszym, (wszystko) dla podniesienia i pokrzepienia pozostałych. I w ten sposób, gdy tak nawzajem się wymieniają, braterskie współczucie wynikające z miłości (compassio fraterna) przenika przez nich wszystkich. Zawsze troszczą się o to, aby głowa i rogi były trzymane w górze i widziane i nie zanurzyły się w głębinach strumienia ${ }^{37}$.

35 Ps 41,2: „Jako pragnie jeleń do źródeł wodnych, tak pragnie dusza moja do ciebie, Boże" (przekład Jakuba Wujka). Tłumaczenie zaproponowane przez Biblię Tysiąclecia (,Jak łania pragnie wody ze strumieni [...]”), nie byłoby w pełni zrozumiałe w świetle podjętych przez Dhuodę metaforycznych interpretacji, które ściśle dotyczyły wspomnianych tutaj słów psalmisty.

36 Liber manualis III 10, SCh 225, 178: „Nam quidem doctor de similitudine animalis mutis ob aedificationis exemplo, magnum et lucidissimum in brui transcurrit".

37 Liber manualis III 10, SCh 225, 178: „Cerui hanc habent consuetudinis morem, ut, cum pluraliter maria uel spatiosa maritimis undarum gurgitis flumina transuehi coeperint, unus post unum caput cum cornibus super dorsa compari suo colla submittant, ut paululum quiescentes facilius amnem possint transcurrere ueloces. Est in illis talis intellectus et talis aequa discretio, ut, cum priorem senserint adgrauari, mutant primum posteriorem, et extremum, ad ceteros subleuandum uel refocilandum, eligunt primum; sicque in singulis uersa uice mutantes, talis per singula in illis transcurrit compassio dilectionis fraterna: hoc semper cauentes ut caput cum cornibus, ne in amnis mergantur profundis, super ostendi et anefari satagunt”. Por. Augustinus, Enarrationes in Psalmos, PL 36, 466. „Otóż powiadają, że jelenie, kiedy idą w swoim szyku albo kiedy płynąć zdążają do innych okolic, ciężar swoich głów kładą jeden na drugim tak, że jeden idzie z przodu, a te, 
Instynktowne zachowanie jeleni, które znalazło swoje miejsce we wczesnośredniowiecznych mistycznych rozważaniach na temat wspólnoty chrześcijańskiej, zaczerpnięte zostało jeszcze z literatury klasycznej. O rogaczach płynących w samozachowawczym szyku pisał bowiem Pliniusz Starszy ${ }^{38}$, Solinus $^{39}$ i Klaudiusz Elian ${ }^{40}$. W wyobrażeniu Dhuody stadem wzajemnie wspierających się jeleni miała być nie tylko - w sposób ogólny - społeczność chrześcijańska, chodziło jej również o najbliższe otoczenie Wilhelma czy wreszcie królewski dwór. Wszyscy jego członkowie powinni wzajemnie oraz korzystnie sobie służyć $\mathrm{i}$ - co podkreślała autorka - znosić także słabości tych najmniejszych, nie uciekając jedynie do ludzi swojej rangii ${ }^{41}$. Tak

które za nim idą każdy na swoim poprzedniku kładzie głowę i tak aż do końca szyku. Ten pierwszy, który na początku dźwigał ciężar głowy, kiedy się zmęczy idzie do tyłu, a inny go zastępuje niosąc to, co tamten, tamten zaś zmęczenie swoje rekompensuje położeniem głowy tak samo jak inne jelenie. Tak kolejno dźwigają to, co ciężkie i drogę przebywają i wzajemnie od siebie nie odstępują. Czyż nie do takich jeleni zwraca się Apostoł ze słowami: «Jeden drugiemu brzemiona noście, a tak wypełniajcie Prawo Chrystusowe»". Tł. J. Sulowski, Św. Augustyn, Objaśnienia Psalmów 41, 4, PSP 38, Warszawa 1986, 125. Por. Gregorius Magnus, Moralium Libri sive Expositio in Librum Beati Job 30, 39, 1, PL 76, 543-544. „Mówi się zaś, że jeśli zdarzy się im przechodzić przez rzekę, ciężar swojej głowy składają na grzbiet tych, które idą przed nim, i wspierając siebie nawzajem, nie czują żadnego trudu wynikającego z ciężaru. [...] Dlatego psalmista mówi: «Jak jeleń pragnie wody ze zdroju, tak dusza moja pragnie Ciebie, Boże». Oni także, przechodząc także przez niepewne chwile doczesności jak przez swego rodzaju rzekę, nakładają na siebie nawzajem ciężary pełni współczucia wynikającego z miłości; ponieważ niosą je z wielką troską, zachowują to, co napisano: «Jedni drugich brzemiona noście, tak postępując, wypełniajcie wolę Chrystusa»”. Tł. A. Wilczyński, Św. Grzegorz Wielki, Moralia. Komentarz do Księgi Hioba 30, 39, 1, t. 6, ŹM 77, Kraków 2016, 186-187.

38 Por. Caius Plinius Secundus, Naturalis historiae 8, 50, red. C. Mayhoff, Leipzig 1875, 84: „Maria trameant gregatim Nantes porrecto ordine et capita imponentes praecedentium clunibus vicibusque ad terga redeuntes" - "Morza przepływają stadami w długim rzędzie, tak iż głowy kładą na tyły płynących przed sobą, a te udają się znowu w tył z kolei”. Tł. J. Łukaszewicz, K. Pliniusza Starszego Historyi Naturalnej ksiag XXXVII 8, 50, t. 3, Poznań 1845, 253.

39 Por. Caius Iulius Solinus, Collectanea rerum memorabilium 19, 9, red. Th. Mommsen, Berlin 1895, 94: „[...] infirmos ponunt in ultimo et lassorum capita clunibus per vices sustinent".

40 Por. Claudius Aelianus, De natura animalium 5, 56, red. R. Hercher, Paris 1858, 93: ,[...] tum fidenti animo mare ingrediuntur et ordine natant; et in antecedentium tergo subsequentes capita reponunt; jam qui agmen duxit, ubi lassitudine affectum se intellexerit, retrocedit atque extremi cervi clunibus innixus cogit agmen".

${ }^{41}$ Liber manualis III 10, SCh 225, 172: ,[...] atque te ad illos illosque tibi coniungi, magnis cum paruis in utilitatibus, ne pigeas ortor". 
więc obowiązkiem potężniejszych, wzorem silniejszych jeleni, było zagwarantowanie wsparcia tym pośledniejszym. Każdy wierny chrześcijanin wezwany był do udzielania pomocy na miarę swoich możliwości. I jak pouczała karolińska uczona: „Ci, którzy mogą, powinni tych (mniejszych) wspierać i [...] nosić ich brzemiona, silni te słabsze, potężni te pośledniejsze, tak aby słabsi — pozyskując siłę mocarzy - wraz z silniejszymi mogli wznieść się ku obiecanym wyżynom przodków"42.

Compassio fraterna wiązała się więc $\mathrm{z}$ miłosierdziem, wielkodusznością i bezinteresowną troską. Zawierała w sobie niesienie pomocy oraz zrozumienie wobec bliskich, gorliwą gościnę dla przybyszów, a także nieustanne pokrzepianie biednych i pogrążonych w smutku. Jeżeli Wilhelm będzie potrafił konsekwentnie okazać swe współczucie na rzecz wszystkich otaczających go braci mniejszych, wówczas, jak przekonywała matka, Duch Święty obdarzy go prawdziwym darem pobożności ${ }^{43}$. Wielokrotnie pouczała syna, aby szukał przykładów braterskiej miłości w księgach Bożego pisma, które wzywały do doskonalenia się i nasycania współcierpieniem bliźnich. Wspólnota uczuć nie polegała jednak tylko i wyłącznie na słownym uzewnętrznianiu swego żalu. Wilhelm miał słowa zamieniać w czyny, czyli konkretną i skuteczną pomoc dla, jak szczegółowo wyliczała Dhuoda, ubogich, nieszczęśliwych, pielgrzymów, wdów, sierot, nieletnich dzieci czy też ludzi o mniejszym znaczeniu i wpływach. Kierując się Pismem Świętym, tłumaczyła pierworodnemu synowi, że w obliczu Boga wszyscy są przybyszami, gośćmi i pielgrzymami ${ }^{44}$. Prawdziwa compassio fraterna zamieniała współczującego we wspólnika (socius) danej troski. Dodatkowo potrafiła wyzwolić w nim moc przekonywania tych, którzy następowali po nim, aby podążali jego drogą i realizowali to samo wielkie dzieło wzajemności ${ }^{45}$. W obrazie naszkicowanym przez karolińską autorkę

42 Liber manualis III 10, SCh 225, 174: „Debent eos qui possunt adiuuare, et, [...] onera sua alterutrum portare, firmi infirmiora, capaces minora, ut inferiores cum firmis capax uigorum ad alta ualeant scandere prolixa maiorum".

43 Liber manualis IV, 4, SCh 225, 216: Si compassionem erga proximos habueris fraternam, et hospitalium sectator, pauperumque et moerentium consolator assiduus fueris, habebis spiritum pietatis".

44 1Krn 29,15: „Jesteśmy bowiem pielgrzymami przed Tobą i przychodniami, jak byli wszyscy przodkowie nasi [...]" (BT).

45 Liber manualis IV, 8, SCh 225, 236-238: „Si obuius fueris pauperi et inopi, non solum uerbis, sed etiam factis, adiutorium illis, ut uales, inpende. Similiter et peregrinis ospitium ut tribuas libenter admoneo, atque etiam uiduis orphanisque, nec non et pupillis minusque agentibus, siue illos quos in egestate conspexeris esse positos, manum ad opus subleuare frequens. Nam omnes nos, ut ait Scriptura, «aduenae sumus», incolae et «peregrini, sicut patres nostri» uoluentium in terra. Lege Mosaicae admonitionis Israeli filios ad 
wyraźnie dostrzec można symboliczny szyk wspartych na sobie chrześcijan, którzy wspólnie pokonują przeszkody doczesnego świata. Słabsi ufali silniejszym. Silniejsi zaś, powodowani empatią, nie zwlekali z niesieniem podpory dla obolałych i znużonych.

$\mathrm{Z}$ jednej strony mamy do czynienia z proklamowaną przez markizę cnotą miłosierdzia, która potężniejsi mieli okazywać i realizować względem słabszych, z drugiej zauważamy wyraźny nacisk na pokorę oraz uległość. Te ostatnie szczególnie ćwiczyć powinni ci, którzy znajdowali się niżej w hierarchii społecznej, dworskiej czy wreszcie także wojskowej. Umiejętność uznania własnej ograniczoności oraz ukorzenia się wobec dostojniejszego od siebie była zdaniem karolińskiej uczonej stanem ducha najbardziej podobającym się Bogu. Dhuoda zwracała Wilhelmowi uwagę, że nawet jeżeli będzie on swoją rangą najmniejszy pośród wszystkich otaczajacych go towarzyszy broni, to niechaj znajdzie w sobie odwagę, aby gorliwie podążać i mieć na względzie postawy oraz postępowanie tych znamienitszych. Wielkich (magnos) niechaj traktuje tak, jak gdyby byli wywyższeni (sublimes), równych zaś (aequales) sobie, jak gdyby byli szacowniejszymi (altos), ponieważ to razem z nimi będzie on mógł ubiegać się o wywyższenie swoich godności ${ }^{46}$. Arystokratka błagała pierworodnego syna, aby szczerze potrafił cieszyć się wespół z tymi, którzy dostępują awansu. Był to w jej opinii dowód prawdziwej pokory i uległości ${ }^{47}$.

Symboliczny jeleni szyk stał się dla Dhuody nie tylko doskonałą metaforą braterskiej współodpowiedzialności i jednomyślności. Tę zresztą wykorzystała, podążając za przykładami znanych jej doktorów Kościoła. Odwołując się do zwierzęcych zwyczajów, uczona odważyła się pójść o krok dalej od wcześniejszych interpretacji. Zachowanie jeleni poddała dalszym, osobistym i dość odważnym rozważaniom. W zwierzętach dostrzegła nie tylko uosobienie kochających się i współczujących sobie bliźnich, ale także odważnych i pełnych nadziei wyznawców Chrystusa, którzy nie poddają się, aby stale wznosić ku górze swoje serca na podobieństwo

compassionem satiari fraternam; ualde eos ortabatur, dicens: «Mementote quoniam et uos ipsi aduenae et peregrini fuistis in terra Aegipti». De peregrinis namque et uiatoribus, quidam, ex compassione fraterna, ut socius adesset et posteros in hac simili confessione futuris secum colligeret et in opus sociaret magnum, ita dicebat: «Ostium meum uiatori patuit»"

46 Liber manualis III 10, SCh 225, 174: „Tu ergo, licet inter comilitones minimus esse uidearis in formam, tamen sensu tenax uigorum et formam exemplis magnorum, $[\ldots]$, attentius intueri et sequi ne pigeas ortor, fili. Magnos ut sublimes, aequales ut Altos, consimiles praepone, ut tibi una cum illis profectum dignitatis adquiri possis maiorum; $[\ldots]$ ".

47 Liber manualis III 10, SCh 225, 174: ,[...] omnibus namque per subiectionum humilitatis exempla tuis praelatos esse congaudeas, obsecro". 
jelenich rogów. Nie powinniśmy pozwolić, jak czytamy w Liber manualis, aby serca nasze i umysły uwięzione zostały w otchłani, którą wypełnia błoto zepsucia i żądzy. Dążeniem ludzi, na co wskazywała Dhuoda, powinno być ciągłe kierowanie serc do Boga, ponieważ tam znajduje się nasz sposób na życie, nasza siedziba i świadectwo wszelkiej moralności. Drogę wskazał śmiertelnikom sam Chrystus, który jako pierwszy uniósł „róg swej zbawczej mocy" 48 .

Z każdą kolejną, kierowaną do Wilhelma, zwierciadłową admonicją poznajemy coraz pełniejsze matczyne wyobrażenie braterstwa. Możemy stwierdzić, że wzorem głoszonej przez Dhuodę idealnej compassio fraterna była tylko ta, która objawiała się poprzez ciągłe uaktywnianie chrześcijańskiego miłosierdzia, pokory, lojalności, jedności i bezinteresownej pomocy. Każda z tych wartości stawała się prawdziwa i możliwa do zrealizowania w kontekście całkowitego zawierzenia się Bogu i uznania Go za źródło i cel ludzkich czynów. Cnoty, które wskazywała autorka, były jednocześnie warunkiem nieodzownym dla osiagnięcia absolutnego braterstwa ciał i dusz. Chodziło jej o wymiar braterstwa trwale łączącego członków całej wspólnoty, książęcego dworu czy wreszcie rodziny. Zaprojektowany przez markizę Septymanii wzorcowy obraz familiarnej jedności wyposażony był w jeszcze jedną istotną wartość, nieco jednak nieuchwytną w odniesieniu do stanowej rzeczywistości karolińskiej. Dhuoda bowiem marzyła o wprowadzeniu pełnego braterstwa apostolskiego, którego wyznacznikiem byłaby także równość. Swoje refleksje na ten temat rozpoczęła od przywołania fragmentu z Dziejów Apostolskich: „«Pośród nich nikt nie cierpiał niedostatku» (Dz 4,34), «ale wszystko mieli wspólne», w Bogu pokładali «Jedno serce i jedną duszę» (Dz 4,32)"49. Dzieje uczniów Chrystusa działały na autorkę podręcznika niezwykle inspirująco. Widziała w nich program reformy dla świeckiej społeczności swoich czasów. Nie miała wątpliwości, że możliwe jest, aby kształtować chrześcijańskie życie laickiej części społeczeństwa na kanwie praktyk znanych ze świadectw na temat pierwszej

48 Liber manualis III 10, SCh 225, 180: „In eleuationem uel erectionem capitarum cornuumque ostendunt fideles in Christo sursum semper tenere cor et mentem semper in illum habere. Qui ortus Rex ex semine Dauid pro salute generis humani, in fluctuationis mare undarum, ad imma descendens, ad suos liberandum erexit cornu, atque libere egens hos quos in umbra inuenit iacentes, oriens ex alto uisitauit et erexit ad summum, dans exemplum ne in fluctuationem uel gurgitis maris, libidinum atque cupiditati coeno limoque obuoluto, sursum erigentes teneamus cum Apostolo cor, dicentesque: «Nostra autem conuersatio in coelis est»".

49 Tłumaczenia z Biblii Tysiąclecia. Por. Liber manualis III 10, SCh 225, 178-179: «Non enim erat quisquam egens inter illos, sed erant illis omnia comunia», habentes in Deum «cor unum et anima una». 
wspólnoty uczniów Chrystusa w Jerozolimie ${ }^{50}$. Choć wspólnota ta stawała się przede wszystkim wzorcem dla pierwszych monasteriów i uprawianych w nich ascetycznych praktyk, to jednak nie przeszkadzało to karolińskiej pisarce interpretować ją jako niezastąpione źródło inspiracji także dla aktywnego życia świeckich. W tym miejscu objawiają się nadzieje Dhuody na możliwe uzdrowienie społeczeństwa, które dotknięte było rozlewem krwi i nienawiścią, w duchu apostolskiej jednomyślności serca i duszy ${ }^{51}$.

Braterska wspólnota oznaczała więc według markizy Septymanii nieustanną praktykę współodpowiedzialności, dyktowała także symboliczną równość. Była to równość, która wynikała z człowieczej natury. Tę równość zapowiadała pokora wcielonego Boga, który w ziemskim życiu wyrzekł się swojego majestatu i uniżył sam siebie. On jako największy stwórca wszechrzeczy potrafił przyjąć postać sługi i swoją obecnością przemówił na korzyść tych najmniejszych ${ }^{52}$. Bóg przyznaje ludziom dobrodziejstwa, jak czytamy w Liber manualis, tylko na podstawie swojej własnej miary, a nie ziemskich zaszczytów i godności ${ }^{53}$. W obliczu Bożej sprawiedliwości wszyscy byli równi. Równymi stawali się także w chwili śmierci. Dhuoda przekonywała Wilhelma, że tak samo umrze zarówno bogacz, jak i biedak. Co więcej, cierpią oni jednakowe troski i udręki. Każdy z nich może stać się ofiarą tego samego grzechu:

Bogacz i biedak razem umrą, razem mogą także cierpieć niedostatek. Bogacz nie zgadzając się, (ażeby dać), biedak nie mając nic (czego pragnie). Podczas gdy śpią, jednakowy ciężar ich przygniata. Oni nie mają w sobie ducha pokory ani nie spoczną w duchu ubóstwa, które należy do (Chrystusowych) błogosławieństw. Błąkają się i dręczą tym, co znienawidzone jest przez wielu. Powiedział pewien: Moja dusza nienawidzi bogacza kłamcy i żebraka pysznego ${ }^{54}$.

50 Por. Olsen, One Heart and One Soul, s. 32.

51 Liber manualis III 10, SCh 225, 180: ,[...] habentes in Deum «cor unum et anima una», compassionis fraternitatem in Christo Iesu inuicem semper tenentes" - '[...] mając dla Boga «jeden duch i jedno serce», zawsze i wzajemnie zachowując w Chrystusie Jezusie braterstwo wspólnoty uczuć'.

52 Liber manualis III 10, SCh 225, 172: „Pro minimis suam ad imma dignatus est tellus ostendi praesentiam. Nam, ut aiunt doctores, cum esset summus omniumque creator, formam accipere dignatus est seruilem".

53 Liber manualis III 10, SCh 225, 174: „Ipse humani generis amitor, et magnis et minimis secundum qualitatis mensuram suam, ut uult, non denegat pro meritis beneficia largiri. Non enim «est personarum ecceptor», sed in omnibus «qui timent illum» et eius faciunt uoluntatem placitus adest”.

54 Liber manualis IV 8, SCh 225, 238-240: „«Diues et pauper simul peribunt, simulque in egestate torquescunt, diues non largiens, pauper non habens: hii tales non habent 
Braterstwo równości brało swój początek w cielesnej naturze człowieka ${ }^{55}$. Wszyscy, jak zapewniała karolińska pisarka, wywodzimy się $\mathrm{z}$ jednego ciała i w ten sposób dzielimy wspólną naturę. Antecesor rodu ludzkiego miał przecież w odniesieniu do wywodzącej się z niego kobiety powiedzieć: „To teraz kość z kości moich, i ciało z ciała mego" ${ }^{56}$. Ciało,

spiritum humilitatis, nec in beatitudines spiritu quiescent paupertati». Volitantur enim atque torquentur in eo quod odibile est multis. Ait quidam: «Diuitatem mendacem et pauperem superbum odit anima mea»". Ostatnie zdanie jest parafrazą myśli pochodzącej z Księgi Mądrości Syracha (Syr 25,2): „Trzech rodzajów ludzi znienawidziła moja dusza, a życie ich szczególnie mnie gniewa: żebraka pysznego, bogacza kłamcy, starca cudzołożnego, ogołoconego z rozumu". Całość rozważań Dhuody na temat pragnień cielesnych, które dotykają i bogatych, i biednych zainspirowane zostało Komentarzem do Ksiegi Hioba Grzegorza Wielkiego. Por. Gregorius Magnus, Moralium Libri sive Expositio in Librum Beati Job 15, 56, 65, PL 75, 1115: „W ziemskich sprawach zarówno niegodziwy bogacz, jak i biedak, chociaż nie mają takiego samego powodzenia, niepokojeni są jednakową troską; co jeden z lękiem posiada, ten drugi z troską pożąda, a nie potrafiąc zdobyć, cierpi”. Tł. S. Naskręt - E. Buszewicz - K. Nastał - L. Gładyszewski, Św. Grzegorz Wielki, Moralia. Komentarz do Księgi Hioba 15, 56, 65, t. 3, ŹM 44, Kraków 2007, 277.

55 W parenezie karolińskiej dość często pojawiały się wskazania dotyczące równości ludzkiej natury, która dawała wszystkim śmiertelnikom takie same prawo w dążeniu do Chrystusa i prawdy. Koncepcja ta występuje m.in. u Theodulfa z Orleanu (ok. 760821). Zob. Theodulfus episcopus, Versus contra iudices, v. 895-896, red. E. Dümmler, MGH, Poetae 1, Berlin 1881, 516: „Bądź najłagodniejszym i mniej na uwadze ubogich. Zrozumiesz, że jesteś im równy z natury" (tł. autorki). O równości wypowiadał się także Jonasz z Orleanu (De institutione laicali 2, 22, PL 106, 213), który wiernie zresztą w tym miejscu cytował koncepcję aequitas wyłożoną przez Grzegorza Wielkiego. Zob. Gregorius Magnus, Moralium Libri sive Expositio in Librum Beati Job 21, 15, 22, PL 76, 203: „[...] natura zrodziła wszystkich ludzi równymi, lecz ze względu na różność zasług, ukryte zarządzenie kładzie jednych ponad drugimi. Sama zaś nierówność, która powstała wskutek występku, słusznie została uporządkowana według Bożych wyroków, aby jeden stał się poddanym drugiego, skoro nie wszyscy ludzie idą drogą życia właściwie”. Tł. E. Buszewicz - A. Wilczyński, Św. Grzegorz Wielki, Moralia 21, 15, 22, ŹM 63, Kraków 2013, 352-353. Papież Grzegorz Wielki temat równości podjął też w Księdze reguty pasterskiej. Zob. Gregorius Magnus, Regulae pastoralis liber 2, 6, PL 77, 34: „[...] natura wszystkich ludzi równymi zrodziła, lecz przez zmienny porządek zasług wina stawia jednych w tyle drugich. Sama zaś odmienność, pochodząca z występku, wyrokiem boskim jest zrządzona, aby - ponieważ wszelki człowiek nie zdoła stać równo - jeden drugim kierował”. Tł. J. Czuj, Grzegorz Wielki, Księga reguły pasterskiej 2, 6, POK 22, Poznań 1948, 49.

56 Rdz 2,23 (tł. Jakuba Wujka). Por. Liber manualis IV 9, SCh 225, 256-258: „Carnem hic fraternam conditionem desygnat, ex qua nos cum omnibus originem trahimus, ipsi dicente protoplasto sibi simili iuncto: «Hoc nunc os ex ossibus meis, et caro de carne mea»". 
które było wspólne dla wszystkich ludzi, nazwę swą (caro) wzięło od cadendo, czyli upadania. Cieleśnie więc, gdy przyjdzie koniec, w ten sam sposób bogaty oraz biedny, co czytamy dalej, razem upadną, aby potem zmartwychwstać. Zamykając swe rozważania, Dhuoda przywołała biblijną istotę człowieczeństwa, której wymowa koncentrowała się na słabości cielesnej powłoki. Człowiek, o czym przypominał sam Bóg, był jedynie prochem i w ten sam proch się obracał $(\operatorname{Rdz} 3,19)^{57}$.

W kontekście pojawiającej się w Liber manualis równości na uwagę zasługuje fakt, że Dhuoda umieszcza ją każdorazowo w tych miejscach rozprawy, które odnosily się do miłosierdzia względem słabszych i biednych. Tylko czynne miłosierdzie pozwalało dostrzec problemy bliźnich. Zbliżało więc do siebie śmiertelników i stawiało ich w jednym szeregu. Miłosierdzie otwierało też drogę pokorze, która umożliwiała zbudowanie pełnego i dogłębnego braterstwa bogatych z biednymi.

Karolińska arystokratka wyjaśniała dalej, że choć ludzie byli równi z natury, to Bóg ustanowił nad nimi królewską rangę i nadał im seniorów oraz zwierzchników, którym należało służyć wiernie i pożytecznie $e^{58}$. Członkowie klasy panującej zobowiązani byli do sprawowania - w służbie Bogu i świętym - odważnych rządów nad światem i ludźmi. Mieli kierować i chronić swoją społeczność przed czyhającym w ukryciu wrogiem, a także dazżyć do trwałej jedności Kościoła i religii ${ }^{59}$. Obowiązkiem arystokracji, czyli w ujęciu autorki tych, którzy zyskiwali więcej poprzez swe zasłu-

57 Por. Liber manualis IV 9, SCh 225, 258: „Karo namque a cadendo nomen accepit, ea vero tenore rationis mensura, licet cadat, licet resurgat, tam pauper quam diues, omnes per finem, in puluerem reuententur". Etymologiczny rodowód słowa caro, który prowadził do czasownika cadere, znajdujemy u Augustyna. Por. Augustinus, De civitate Dei 20, 10, PL 41, 675: „Upadają zaś ciała przez śmierć, bo i od słowa cadere (padać) pochodzi nazwa cadavera (trupy, padlina). Nie może więc, powiadają, być zmartwychwstania dusz, lecz ciał". Tł. W. Kubicki, Św. Augustyn, Państwo Boże 20, 10, Kęty 2002, 819.

58 Por. Liber manualis III, 8, SCh 225, 168: „Tu ergo, fili Wilhelme, obtempera iugum famulantis normam, sisque fidelis seniori tuo Karolo, quisquis ille est, et suis dignis utrorumque sexuum parentibus atque regalium generis ortos. Est enim dignum ita agere tibi, et omnibus in illorum regni imperio militantibus, totis nisibus te inter eos utiliter atque fideliter obto seruiendum" - 'Ty zatem, synu Wilhelmie, bądź posłuszny powinności i regule służenia, bądź wierny seniorowi twojemu Karolowi, jakkolwiek przedstawia się jego sytuacja (polityczna), bądź wierny jego szlachetnym przodkom obojga płci oraz wszystkim potomkom królewskiego rodu. Ponieważ powinieneś w ten sposób czynić zarówno ty, jak i wszyscy wojownicy, którzy służą królewskiej władzy. Proszę cię, abyś ze wszystkich sił zobowiązał się do służenia im, wiernie i pożytecznie".

59 Por. Liber manualis III, 8, SCh 225, 168-170: „[...] mundumque cum populo, in Dei et sanctorum seruitio, uiriliter regere, protegere, gubernare, et ab hostium inimi- 
gi i godność, było niesienie pomocy oraz pocieszenia tym najmniejszym. Przekonanie o spoczywającym na elitach społecznych tzw. altruistycznym ministerium autorka potwierdzała następującymi słowami:

Jednak ci, którzy poprzez swoje zasługi zyskują więcej, godzi się, aby zrozumieli, że należy pomagać i wspierać w różnych sytuacjach. Za sprawą braterskiego miłosierdzia (compassio fraterna), abyś zrozumiał i pobożnie dopomógł, współczując tym wszystkim głodnym, spragnionym, nagim, sierotom, pielgrzymom, przybyszom, wdowom, małym dzieciom, uciskanym oraz potrzebującym. Jeśli to zrobisz, „twoje światło wzejdzie jak zorza” (Iz $58,8)$, a twoje kroki bez przerwy będą rozjaśnione blaskiem ${ }^{60}$.

Pareneza Dhuody obok braterstwa w wymiarze duchowym odwołuje się także, jak zostało to już wspomniane, do braterstwa krwi i modelowych relacji pomiędzy rodzonymi braćmi. Tematyka ta jest w pełni zrozumiała w kontekście rodzinnej i osobistej sytuacji markizy. Była ona matką dwóch męskich potomków, pomiędzy którymi zachodziła znaczna różnica wieku. Wilhelm w chwili, w której skończyła pisać swój pamiętnik, miał siedemnaście lat, Bernard - niespełna dwa. Do napisania dzieła skłoniła ją obok tęsknoty za nieobecnymi w jej życiu synami przede wszystkim choroba i świadomość nieuchronnej śmierci:

Ponieważ nie ma takiej możliwości, aby opóźnił się czas mego odejścia i ból choroby ze wszystkich stron dręczy moje ciało, naprędce złożyłam tę książeczkę, aby pomogła ona tobie i twojemu bratu. Mając zaś świadomość, że nie zdołam dożyć do wspomnianego czasu (waszej dojrzałości), zachęcam cię, abyś kosztował ów pokarm swoimi ustami ${ }^{61}$, podobnie do słodkiego napoju zmieszanego z miodem" "2.

corum undique adsurgentium cuneis tensare atque defendere, sanctamque Dei uidelicet Ecclesiam in religione uera firmius coadunare in Christo; [...]".

60 Liber manualis IV, 8, SCh 225, 258: „Tamen qui pro meritis magnis magna adquirunt, minimos, ut conspexerint, dignum est subleuari et adiuuari in rebus. Fraterna etenim compassione, et in esurientibus, et in sitientibus atque nudis, et in orphanis et in peregrinis, in aduenis, in uiduis seu etiam in pupillis oppressisque et omnibus indigentibus, ut conspexeris, illis miserendo subuenias pie. Quod si feceris, «erumpet quasi mane lumen tuum» et claritas in tuis per cuncta fulgebit gressibus".

${ }^{61}$ Dhuoda ma na myśli słowa, które metaforycznie poprzez głośne czytanie stawały się strawą dla ust (cibus oris). Obraz - w jego wymiarze dydaktycznym i ornamentacyjnym - rozumiano jako strawę dla oczu (cibus oculorum).

62 Por. Liber manualis X, 1, 337: „Sed quia tempus resolutionis non tardat me meum, et aegritudo angustiarum corpus undique conterit istum tibi et fratrii ut prosit, quod collegi 
Matka wyraźnie wskazywała, jakie obowiązki spoczywały na jej wkraczającym w dorosłość synu wobec małoletniego brata ${ }^{63}$. Skala odpowiedzialności, którą obarczyła Wilhelma za los oraz wychowanie maleńkiego Bernarda, pozwala założyć, że nie miała pewności, czy jej małżonek zdoła wypełnić swoje ojcowskie powinności względem synów. Bernard senior utracił zaufanie Karola Łysego i narażony był na szereg niebezpieczeństw. Tymczasem Dhuoda w żadnym miejscu dzieła nie dzieliła się z Wilhelmem informacjami na temat publicznych problemów jego ojca. Nie zabierała także stanowiska wobec wyborów i decyzji swojego męża. Konsekwentnie realizowała patriarchalny porządek, w którym ojciec dysponował władzą absolutną nad żoną i dziećmi. Status męża decydował także o przyszłości żony. Autorka Liber manualis świadomie zbudowała przed synami obraz szlachetnego, pełnego wartości ojca, którego należy kochać, otaczać największym szacunkiem i być mu dozgonnie wiernym. W każdym słowie na temat Bernarda zamknięte było jej zawierzenie, oddanie i lojalność. Jednak głębokie i pełne matczynych emocji prośby, które kierowała do starszego syna, wierząc, że zaopiekuje się on swoim maleńkim bratem, zdradzać mogą gnębiący ją i zatajony niepokój o los całej rodziny. Skoro w Wilhelmie widziała opiekuna młodszego syna, to tym samym musiała także brać pod uwagę, iż Bernardowi nie dane będzie z różnych przyczyn wychować i trwać przy swoich spadkobiercach. Na pierworodnym synu złożyła więc zobowiązanie oraz misję przejęcia opieki i wychowania niesamodzielnego jeszcze Bernarda:

Te słowa, które kieruję do ciebie, czytaj, zrozum i wypełnij działaniem i kiedy twój maleńki brat przyjmie łaskę chrztu w Chrystusie - a nie znam jego imienia - obyś nie miał oporów, aby mu doradzać ${ }^{64}$, wychowywać, kochać i zachęcać go, aby podążał od tego co dobre ku temu co lepsze. Wtedy gdy osiągnie on odpowiedni wiek do tego, aby czytać i pisać, pokaż mu ten mały rękopis Podręcznika, który został przez mnie przygotowany i w twoim imieniu napisany, czytając napominaj go. On jest twoim ciałem

festinans, sciens me ad tempus praedictum peruenire non posse velut mellifluum potum fauisque permixtum, in cibum oris, ut degustes semper adortor".

63 Na temat statusu nieletnich we wczesnym średniowieczu oraz zwyczajowego przejmowania uprawnień opiekuńczych przez starszych braci, zob. Pieniądz, Więzi braterskie we wczesnym średniowieczu, s. 222-223.

64 Dhuoda używa w tym miejscu czasownika insinuare, który oznacza dokładnie 'wpajać, zaszczepiać, komunikować coś komuś, ale także ‘wchodzić w zażyłość i torować (np. drogę do bliskiej przyjaźni i zażyłości)’. W czasowniku tym objawia się pełnia oczekiwań Dhuody w zakresie zadań wpisanych w fizyczną opiekę nad nieletnim bratem. 
i twoim bratem ${ }^{65}$. Napominam was ja Dhuoda, matka każdego z was, abyście nawet udręczeni doczesnymi troskami, stosownie do czasu „trzymali w górę serca ${ }^{66}$. Patrzcie na tego, który rządzi w niebiosach" ${ }^{67}$, on nazywany jest Bogiem ${ }^{68}$.

Zamykając dzieło, autorka skierowała do Wilhelma jeszcze jedną prośbę względem małoletniego Bernarda. Tym razem prosiła i oczekiwała od starszego syna, aby nigdy o niej nie zapominał i przywoływał ją w częstej modlitwie. Miał również utrwalać imię oraz status matki w myślach dojrzałego już i świadomego brata:

Już wcześniej przypomniałam tobie o twoim młodszym bracie także to, co powinieneś względem niego wypełnić, przypominam o tym w dalszym ciągu. Proszę cię, aby i on zechciał, gdy nadejdzie czas jego pełnoletności, modlić się za mnie. Napominam was obu, tak jak gdybyście byli ra-

${ }_{65}$ Karolińska autorka, aby wskazać moc biologicznego braterstwa, przywołała słowa, które wypowiedziane zostały w Księdze Rodzaju przez Judę, syna Jakuba. Juda powstrzymał swoich braci przed nienawistnym planem zabicia najmłodszego z nich, Józefa, sięgając po argument tzw. wspólnoty ciała: ,[...] ręce nasze niech się nie mażą; brat bowiem i ciało nasze (on) jest" (Rdz 37,27 - tł. Jakuba Wujka).

${ }^{66}$ Autorka kilkakrotnie w swoim dziele odwoływała się do idei odważnego i natchnionego braterstwa. We wspomnianej już trzeciej księdze Podręcznika porównywała ludzi związanych braterstwem duchowym do stada jeleni pokonujących rzekę. Wzniesione jelenie rogi oznaczały według niej chrześcijańskie serca, które zawsze powinny wyrywać się do Boga.

67 Fragment na podstawie Passio Sancti Symphoriani, PG 5, 1467: „Sursum cor suspende, fili, aspice illum qui regnat in coelis". Kult św. Symforiana z Autun był w szczególny sposób rozpowszechniony w karolińskiej Francji. Fragmenty ze spisanego męczeństwa Symforiana weszły na stałe do liturgii godzin. Sekwencja, która pojawia się w Liber manualis, znalazła się także w antyfonie jutrzni na uroczystość Wniebowzięcia Najświętszej Marii Panny. Zob. Gregorius Magnus, Antiphonae in matutinis de sancto Sumphonario, w: Liber responsalis sive antiphonarius, PL 78, 800.

68 Liber manualis I 7, SCh 225, 116: „Haec uerba a me tibi directa lege, intellige et opere comple, fratremque tuum paruulum, cuius modo inscia sum nominis, cum baptismatis in Christo acceperit gratiam, insinuare, nutrire, amare, ac de bono in melius prouocare ne pigeas, atque hunc codicellum Manualis a me comprehensum, et in tuo nomine conscriptum, cum perfectum loquendi uel legendi acceperit tempus, illi ostende, et admone legendo; caro enim et frater tuus est. Admoneo uos iam quasi utrosque ego Dhuoda genitrix uestra, ut, inter mundanas saeculi curas obpressi, psaltim ad tempus «sursum teneatis cor; aspicite regnantem in coelis illum qui dicitur Deus»". 
zem, zechciejcie zanosić często w mojej intencji dary ofiarne wraz z ofiarą hostii ${ }^{69}$.

Wyraźnie zauważamy, że biologiczne braterstwo trwało według Dhuody w ścisłym zespoleniu z braterstwem duchowym. Autorka wskazywała na niezbędny w relacji między rodzeństwem aspekt miłości, wsparcia i zrozumienia, czyli wszystkie te wartości, które definiowały pojęcie wspólnotowej compassio fraterna. Należy jednak odnotować, że duchowe braterstwo krwi, które Dhuoda przedstawiła na bazie oczekiwanej przez nią współzależności między Wilhelmem i Bernardem, obejmowało w sobie też rejestr bardziej szczegółowych tzw. opiekuńczych zobowiązań, które świadczyć winien starszy brat wobec młodszego. Pojawił się więc tutaj aspekt wychowawczy i edukacyjny, a także szeroko pojęta opieka nad nieletnim. Nadzór, o jaki prosiła Wilhelma matka, porównywalny był właściwie w pełni do typowej kurateli rodzicielskiej. Możemy więc stwierdzić, że Dhuoda pragnęła, aby Wilhelm pod nieobecność ojca zastępował go niesamodzielnemu jeszcze Bernardowi. Obaj połączeni prawdziwie braterskim przymierzem mieli, według życzeń i pragnień autorki, stanowić ogniwo jeszcze większej wspólnoty braterskiej - wspólnotę dworską czy wreszcie państwową, których spoiwem była compassio fraterna.

Podsumowując, warto przypomnieć, że admonicje autorki względem modelowej braterskiej relacji stanowiły, niestety, jedynie rodzaj projektu życzeniowego $\mathrm{i} \mathrm{w}$ ten sposób odzwierciedlały tylko oczekiwania i wyobrażenie fraternitas, której chciała dla swoich synów. Być może Dhuoda, pisząc swe wzorcotwórcze dzieło, miała szereg obaw co do priorytetów nieobecnego przy niej Wilhelma, a także oddziałujących na niego doradców. Nie można zapominać też, że Bernard z Septymanii - ojciec Wilhelma i Bernarda juniora - oskarżony został przez współczesnych sobie wpływowych możnych o szereg nadużyć, które szkodziły jedności cesarstwa, a tym samym prowadziły do pogwałcenia braterstwa $^{70}$. Podręcznik jest źródłem ściśle powiązanym z realiami spo-

69 Liber manualis X, 4, SCh 225, 352: „De fratre tuo minimo quid erga illum agere debeas, admonui supra, admonui deinceps. Hoc rogo ut, si ad perfectum peruenit tempus, et ipse pro me exorare dignetur. Iam enim quasi utrosque simul admoneo coniunctos, ut sacrificiorum libamina, cum oblationibus hostiarum, pro me frequenter offerre dignemini".

70 Negatywnie na temat Bernarda wypowiadał się choćby Paschazy Radbert w biografii Walii, kuzyna Karola Wielkiego. Por. Paschasius Radbertus, Epitaphium Arsenii seu Vita venerabilis Walae, PL 120, 1615. „Ów dzień pogrążył świat w niemal wiecznych mrokach kryzysu, rozbił pokojowe i zjednoczone cesarstwo, rozrywając je na kawałki, pogwałcił braterstwo, zerwał więzy krwi, wszędzie zasiał nieprzyjaźń, rozproszył rodaków, wygnał wiarę, zniszczył miłość, zhańbił kościoły i wszystko znieprawił. [...] Niestety, po 
łecznymi i politycznymi, które towarzyszyły karolińskiej arystokratce. Eksponuje sedno trosk i nadziei związanych z jednością państwa, załagodzeniem stosunków między synami Ludwika Pobożnego czy wreszcie szeroko rozumianym pokojem społecznym. Zadedykowany został - w szczególny i osobisty sposób - braterstwu Wilhelma i Bernarda. Pobratymczej wspólnocie krwi, która miała być budowana i rozwijana, zgodnie z życzeniem matki, w oparciu o chrześcijańskie oddanie oraz pełną zażyłość. Pareneza zamknięta w Liber manualis ma jednak, co istotne, wydźwięk w pełni uniwersalny. Jej wzorcotwórcze exempla dotyczą wszystkich braterskich grup i sojuszy, od których jedności i kondycji wewnętrznej zależało braterstwo całej wspólnoty, państwa czy wreszcie władztwa.

\section{Idea compassio fraterna w parenetycznej instrukcji Dhuody z Septymanii} $(\dagger$ ok. 843)

(streszczenie)

Niniejszy artykuł podejmuje temat związany z proklamowaną przez karolińską uczoną, Dhuodę z Septymanii, ideą compassio fraterna, która odnosiła się do zdolności braterskiego współczucia i współcierpienia, rodziła także tak istotną dla chrześcijan duchową więź. Autorka przybliża definicję miłości braterskiej, którą Dhuoda rozważała na płaszczyźnie biologicznej i duchowej. Określiła ona także przynależne jej wartości moralne i płynące z niej wzajemne zobowiązania. W artykule przedstawione zostały źródła, którymi inspirowała się uczona karolińska, kreśląc przed małoletnim synem swoje zwierciadłowe wyobrażenie modelowego chrześcijańskiego braterstwa. Podstawę analiz stanowi jedyne napisane przez markizę Septymanii dzieło - Liber manualis, czyli Podręcznik.

Slowa kluczowe: Dhuoda z Septymanii; karolińskie zwierciadła świeckie; speculum laicalis; fraternitas; braterstwo; piśmiennictwo karolińskie

tym dniu nieszczęścia nastała gorsza jeszcze noc. A żaden dzień nie był bardziej utrapiony od dnia, w którym ten nikczemnik Bernard został wezwany z Hiszpanii, ten nędznik, który porzucił wszelki honor, do jakiego przeznaczyło go pochodzenie. Nurzał się w swej próżności, w rozkoszach stołu. Stał się niczym rozjuszony odyniec; wywrócił pałac; rozbił radę; odrzucił wszelki porządek prawa i rozumu; wypędził, zdeptał wszystkich boskich i ludzkich doradców; zajął cesarskie łoże. [...] Pałac przemienił się w spelunkę, gdzie panuje bezwstyd, rządzi cudzołóstwo, mnożą się zbrodnie, gdzie uprawia się wszelkiego rodzaju zakazane czary i uroki”. P. Riché, Karolingowie. Ród który stworzyt Europę, tł. A. Kuryś, Warszawa 1997, 138. 


\section{The idea compassio fraterna in Paraenetic Instruction of Dhuoda from Septimania $(\dagger$ c. 843)}

(summary)

The present article is about an idea of compassio fraterna which was proclaim by Carolingian scientist Dhuoda from Septimania and was related to ability of brotherly compassion and co-suffering and it was given a birth to a such important thing as a Christian soul bond as well. The author is trying to bring closer the definition of brotherly love which Dhuoda considered on a biological and spiritual level and she defined a belonging to it moral values and flowing from them reciprocal obligations consequent as well. There are pictured a sources which were inspiration for Carolingian scientist who for her juvenile son created her own crystal concept of model-based Christian brotherhood. A base to analisys is a Liber manualis (Handbook) - the only composition written by marchioness Septimania.

Keywords: Dhuoda of Septimania; Carolingian lay mirrors; speculum laicalis; fraternitas; fraternity; Carolingian literature

\section{Bibliografia}

\section{Źródla}

Augustinus, Contra Faustum Manicheum, PL 42, 207-518; tł. J. Sulowski: Św. Augustyn, Przeciw Faustusowi (ks. I-XXI), PSP 55, Warszawa 1991.

Augustinus, Enarrationes in Psalmos, PL 36, 67-1028, tł. J. Sulowski, Św. Augustyn, Objaśnienia Psalmów (Ps 36-57), PSP 38, Warszawa 1986.

Caius Iulius Solinus, Collectanea rerum memorabilium, red. Th. Mommsen, Berlin 1895. Caius Plinius Secundus, Naturalis historiae, red. C. Mayhoff, Leipzig 1875; tł. J. Łukaszewicz, K. Pliniusza Starszego Historyi Naturalnej ksiag XXXVII, t. 3 (ks. 7-9), Poznań 1845.

Claudius Aelianus, De natura animalium, red. R. Hercher, Paris 1858.

Concilium Aquisgranense, red. A. Werminghoff, MGH, Conc. 2,2, Hannover 1908.

Concilium Parisiense, red. A. Werminghoff, MGH, Conc. 2,2, Hannover 1908.

Dhuoda, Liber manualis Dhuodane quem ad filium suum transmisit Wilhelmum, red. P. Riché, SCh 225, Paris 1997.

Epistolae Herchenefredae, w: Vita Desiderii Cadurcae urbis episcopi, red. B. Krusch, MGH, SS rer. Merov. 4, Hannover 1902, 569-570.

Gregorius Magnus, Moralium Libri sive Expositio in Librum Beati Job, PL 76, 9-782; tł. A. Wilczyński, Św. Grzegorz Wielki, Moralia. Komentarz do Księgi Hioba, t. 6 (ks. XXVIII-XXXII), ŹM 77, Kraków 2016; tł. S. Naskręt - E. Buszewicz - K. Nastał - L. Gładyszewski, Św. Grzegorz Wielki, Moralia. Komentarz do Księgi Hioba, t. 3 (ks. XI-XVI), ŹM 44, Kraków 2007. 
Gregorius Magnus, Regulae pastoralis liber, PL 77, 13-125; t1. J. Czuj, Grzegorz Wielki, Księga reguly pasterskiej, POK 22, Poznań 1948.

Gregorius Magnus, Liber responsalis sive antiphonarius, PL 78, 725-850.

Isidorus, Etymologiarum libri XX, PL 82, 9-728.

Isidorus, Sententiae differentiarum de activa vita atque contemplativa, PL 83, 1243-1248.

Jonas Aurelianensis Episcopus, De institutione laicali, PL 106, 121-278.

Paschasius Radbertus, De fide, spe et charitate, PL 120, 1387-1490.

Paschasius Radbertus, Epitaphium Arsenii seu Vita venerabilis Walae, PL 120, 1557-1650.

Passio Sancti Symphoriani, PG 5, 1463-1468.

Probus Donatus Servius, Ars Minor, w: Grammatici Latini, vol. 4, red. H. Keil, Leipzig 1864.

Rabanus Maurus, Homiliae de festis praecipuis, PL 110, 9-134.

Theodulfus episcopus, Versus contra iudices, red. E. Dümmler, MGH, Poetae 1, Berlin $1881,493-517$

\section{Opracowania}

Bessmertny Y., Le monde vu par une femme noble au IXe siècle. La perception du monde dans l'aristocratie carolingienne, „Le Moyen Âge. Revue d'histoire et de philologie” 93 (1987) 161-184.

Bianco M.G., Aspetti di quotidianità culturale nel Liber Manualis di Dhuoda: Il libro, l'autrice, il destinatorio, w: Percepta rependere dona. Studi di filologia per Anna Maria Luiselli Fadda, red. C. Bologna - M. Mocan - P. Vaciago, Firenze 2010, 1-19.

Brunhölzl F., Geschichte der lateinischen Literatur des Mittelalters, t. 1, Munich 1975.

Cherewatuk K., Speculum Matris: Dhuoda's Manual, „Florilegium” 10 (1988-1991) 4964.

Claussen M.A., God and Man in Dhuoda's Liber Manualis, w: Women in the Church, red. W.J. Sheils - D. Wood, Studies in Church History 27, Oxford 1990, 43-52.

Claussen M.A., Fathers of Power and Mothers of Authority: Dhuoda and the Liber manualis, ,French Historical Studies” 19 (1996) nr 3, 785-809.

Dronke P., Women writers of the middle ages. A Critical Study of Text from Perpetua to Marguerite Porete, Cambridge 1984.

Garver V.L., Women and Aristocratic Culture in the Carolingian World, London 2009.

Hummer H., Vision of Kingship in Medieval Europe, Oxford 2018.

Löfstedt B., Zu Dhuodas Liber Manualis, „Arctos” 15 (1981) 67-83.

Malan R., The Ancestry of Dhuoda, Duchess of Septimania, „The Genealogist” 11 (1997) nr 1, 116-126.

Manitius M., Geschichte der Lateinischen Literatur des Mittelalters, t. 1, München 1959. 
Marchand J., The Frankish Mother. Dhuoda, w: Medieval Women Writers, red. K.M. Wilson, Manchester 1984, 1-29.

Mayeski M.A., Dhuoda. Ninth Century Mother and Theologian, Scranton 1995.

Meyers J., Dhuoda et la Justice d'après son Liber Manualis (IX siècle), „Cahiers de Recherches Médiévales et Humanistes. Journal of Medieval and Humanistic Studies” 25 (2013) 451-462.

Misch G., Geschichte der Autobiographie, t. II/1-2, Frankfurt 1955.

Nachtmann D., Einleitung, w: Hinkmar von Reims, De cavendis vitiis et virtutibus exercendis, red. D. Nachtmann, MGH, QQ zur Geistesgesch. 16, München 1998, 1-98.

Nelson J.L., Women and the world in the earlier middle ages, w: Women in the Church, red. W.J. Sheils - D. Wood, Studies in Church History 27, Oxford 1990, 53-78.

Nelson J.L., Dhuoda, w: Lay intellectuals in the Carolingian world, red. P. Wormald - J.L. Nelson, Cambridge 2007, 106-120.

Olsen G.W., One Heart and One Soul (Acts 4:32 and 34) in Dhuoda's Manual, „Church History" 61 (1992) nr 1, 23-33.

Pieniądz A., Więzi braterskie we wczesnym średniowieczu. Wyobrażenia i praktyka spoteczna, Tyniec 2014.

Raby F.J.E., A History of Secular Latin Poetry in the Middle Ages, t. 1-2, Oxford 1957.

Riché P., Karolingowie. Ród który stworzyt Europę, tt. A. Kuryś, Warszawa 1997.

Rodriguez M., Los Salmos bíblicos como enseñanza en el Manual de Dhuoda, w: Actas III Congreso Hispánico de Latín Medieval, t. 2, León 2002, 447-456.

Sedlmeier F., Die laienparänetischen Schriften der Karolingerzeit. Untersuchungen zu ausgewählten Texten des Paulinus von Aquileia, Alkuins, Jonas'von Orleans, Dhuodas und Hinkmars von Reims, Neuried 2000.

Stone R., Morality and Masculanity in the Carolingian Empire, Cambridge 2012.

Toubert P., La théorie du mariage chez les moralistes carolingiens, w: Il matrimonio nella società altomedievale, 22-28 aprile 1976, t. 2, Spoleto 1977, 233-285.

Vones-Liebenstein U., Das Manuale der Dhuoda. Ein fürstenspiegel in form des briefes einer mutter an ihren sohn, w: Epistola 1. Écriture et genre épistolaires IV-XI siècle, red. T. Deswarte - K. Herbers - H. Sirantoine, Madrid 2018, 273-286.

Wemple S., Women in Frankish Society, Philadelphia 1984.

Wollasch J., Eine adlige Familie des früher Mittelalters. Ihr Selbstverständnis und ihre Wirklichkeit, „Archiv für Kulturgeschichte” 39 (1957) 150-188. 
